\title{
Vegferð Læknablaðsins og ógnir við velferð sjúklinga
}

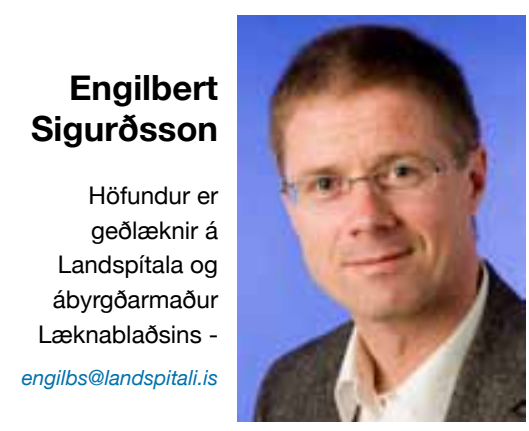

Aldarafmælis Háskóla Íslands hefur verið minnst með margvíslegum hætti. Læknablaðið hefur vottað skólanum virðingu sína í leiðurum og greinum og hyggst í næstu blöðum fjalla sérstaklega um doktorsvarnir við læknadeild á afmælisárinu. Blaðið er sjálft á 97. árgangi en er í stöðugri próun. Nú eru rúmlega 20 árgangar (1990-2011) komnir inn á Medline auk pess sem blaðið er á gagnagrunnunum Web of Science og Scopus. Stöku læknar hafa óskað eftir pví í vetur að birtar verði leiðbeiningar um ritun vísindagreina í blaðinu. Pví er við hæfi að birta í pessu tölublaði stutta yfirlitsgrein um ritun fræðigreina, par sem Einar Stefánsson prófessor, heiðursvísindamaður ársins á Landspítala, miðlar ásamt meðhöfundum af reynslu sinni á pví sviði. Ritstjórn Lxknablaðsins hefur jafnframt endurskoðað leiðbeiningar blaðsins um ritun fræðigreina. Leiðbeiningarnar standa á gömlum merg og grundvallast á reglum sem ritstjórnir ritrýndra vísindarita hafa komið sér saman um og kenndar eru við Vancouver (icmje.org). Petta er priðja endurskoðun á sex árum. Í petta sinn má pó segja að endurritun eigi frekar við en endurskoðun. Drög að nýjum leiðbeiningum eru komin á heimasíðu blaðsins. Ritstjórn hvetur höfunda fræðigreina til að lesa yfir drögin og senda tillögur og athugasemdir um pað sem peim finnst óljóst eða mega betur fara til ritstjórnarfulltrúa blaðsins. Nýju leið- beiningarnar verða birtar í desemberhefti blaðsins og taka gildi 1. janúar 2012. Par verður skerpt á ýmsu, lengdartakmarkanir endurskoðaðar og ráð til höfunda löguð betur að próun blaðsins síðustu misserin.

Lesendur blaðsins hafa sjálfsagt almennt tekið eftir breytingum á hönnun og umbroti blaðsins frá og með maítölublaði á pessu ári. Breytingarnar miða að pví að auðvelda lestur blaðsins en um leið er rými betur nýtt á síðum pess og aðhalds gætt með pví móti. Einnig er óhjákvæmilegt og eðlilegt að útlit og framsetning efnis sé í stöðugri próun hjá Læknablaðinu ekki síður en öðrum fræðiritum. Auglýsingum hefur fækkað í blaðinu í kjölfar kreppunnar og pví er mikilvægt að lækka prentreikninga og sendingarkostnað til að bregðast við lægri auglýsingatekjum. Pó er rétt að ítreka að útgáfa Læknablaðsins á prenti og rafrænt er mun ódýrari kostur en rafræn útgáfa eingöngu par sem lyfjaauglýsingar eru ekki heimilar á opnum netsíðum. Ritstjórn mun ekki selja aðgang að netútgáfu blaðsins, enda eru áhrif pess mun meiri pegar aðgangur er ólæstur og öllum opinn. Reglulega er vitnað til umfjöllunar í Læknablaðinu í fjölmiðlum og í kjölfarið getur hver sem er farið inn á heimasíðu blaðsins og kynnt sér efnið nánar.

Bryndís Benediktsdóttir heilsugæslulæknir kvaddi ritstjórn Læknablaðsins í maí eftir að hafa setið par frá 1. desember 2005, lengur en nokkur annar að ritstjóra undanskildum. Hannes Hrafnkelsson heilsugæslulæknir tók sæti Bryndísar. Henni eru pökkuð vel unnin störf í págu blaðsins um leið og Hannes er boðinn velkominn til starfa.

Læknablaðið hefur í gegnum árin birt talsvert af aðsendu efni um heilbrigðismál og tekið reglulega viðtöl við lækna, stjórnendur og ráðherra um heilbrigðismál. Kreppan hefur óneitanlega sett mark sitt á íslenska fjölmiðla síðustu prjú ár og minnkað getu peirra til vandaðrar umfjöllunar um heilbrigðispjónustu. Pví tel ég eðlilegt að Læknablaðið fjalli í meira mæli en verið hefur um málefni sem eru ofarlega á baugi og varða próun hennar. Gott dæmi er fækkun íslenskra lækna sem starfa hér á landi og aukinn fjöldi vinnuferða íslenskra sérfræðilækna til Norðurlanda. Hvort tveggja hefur pegar haft umtalsverð áhrif á pjónustugetu í heilsugæslunni og ógnað langtímapjónustu í einstökum sérgreinum á Landspítala. Pví miður er pessi vandi vaxandi og vart ofmælt að hann sé líklega mesta ógnin sem heilbrigðispjónustan stendur frammi fyrir um pessar mundir. Afneitun leysir ekki pennan vanda fremur en annan vanda. Hér er um afar brýnt verkefni að ræða sem stjórnvöld verða að bregðast við nú pegar. Ríkisstjórnin hefur brugðist fljótt við óáran og ógnum á síðustu árum eins og eldgosum, flóðum og jarðskjálftum. Nú verður velferðarráðherra að horfa af raunsæi á verkefnið og vinna hratt og vel að lausnum með læknum. Рað á ekki að fara ofan í skotgrafirnar og halda pví fram að petta sé bara kjarabarátta tengd lausum samningum. Raunar parf ekki að leita langt yfir skammt í leit að lausnum. Einfaldast er að horfa til pess hvernig Norðmenn laða til sín lækna með styrkjum pegar peir flytjast milli landa og leggja áherslu á lífsgæði fjölskyldna peirra. Раð er mun vænlegra en að horfa pröngt á krónur í umslagi og treysta á að vinir og fjölskylda haldi almennum læknum hér og laði sérfræðilækna sem starfa erlendis aftur til Íslands.
The Journal's progress and threats to the welfare of patients

Consultant Psychiatrist, Associate Professor of Psychiatry, University of Iceland Editor-in-Chief of the Icelandic Medical Journal 